\title{
Organising Somalian, Congolese and Rwandan migrants in a time of xenophobia in South Africa: empirical and methodological reflections
}

\author{
Denys Uwimpuhwe and Greg Ruiters
}

\begin{abstract}
Xenophobic practices pervade civil society and the state in South Africa. But its victims are not passive. Academic scholarship has not sufficiently recognised the multiple roles of refugees and asylum seekers migrant organisations in a context where refugees are required to Bself-settle". The dominant methodological focus of existing research has been on the migrant as the individual. This paper's main research objectives are to question this focus and examine evidence of the collective responses to struggles faced by foreign African migrants and refugee groups in Cape Town. Eleven refugee and asylum seeker associations formed by Somalians, Congolese and Rwandan asylum seekers and refugees were investigated, based on extensive interviews with 11 leaders of refugee organisations. These organisations not only strongly defend migrant interests but also project a long-term view of integration into South African society. In addition, the paper concludes by arguing for a shift in the focus of research in order to show that migrant organisations are crucial in an individual's collective security concerns, in advocacy with government institutions and in initiatives to build relationships with South Africans.
\end{abstract}

\section{Introduction}

The major unit of analysis in South African migration research has been the individual refugee and migrant families. However, another significant unit of analysis that has been sorely neglected is refugee and asylum seekers' collective self-organisation. But if, as Portes (1995) argued, migration is rarely a single individual effort, then it is crucial that migrant organisations and networks are made more central. In this article, we argue for such a focus and empirically address the following questions: How significant are migrant organisations and what are the types and scale of activities initiated by these organisations? What relevance do these organisations have for meeting key long-term challenges? Moreover, what methodological significance might be implied in studying organisations? The paper explores the multiple roles played by three clusters of Cape Town's African foreign migrant organisations in a context where refugees and asylum seekers (RAs) are required to "self-settle", find jobs and organise self- protection rather than live in camps. It reviews the relevant existing literature, outlines the local context and elucidates the profile, character and role of RAs associations in this context. 
We focus on three groups (Somali, Congolese and Rwandan) and 11 migrant organisations across Cape Town, although Zimbabwean, Malawians and other nationalities also reside in Cape Town. Nzabamwita (2015, p. 75) argues that, "many immigrants from Somalia, Rwanda and DRC hold refugee status and asylum seeker permits and migrated because of political insecurity making them forced migrants, while Zimbabweans are voluntary migrants whose motive for immigration is economic". The rise of RAs organisations also relates to waves of migration and is based on when and where migrants arrived in South Africa, some are already recognised as nationals, while the later arrivals are regarded as asylum seekers or have already been "processed" and designated by government as formal refugees. Precision is important particularly when speaking of organisations among "vulnerable" populations/national groups. For purposes of this paper, RAs organisations are defined as formal organisations/associations operating in public with members and using volunteers.

We highlight and compare the types of RAs organisations, their characteristics, when they were formed, location, membership and their objectives in the first part of the paper. Then, we move on to consider their activities and the efforts by organised migrant groups to assist their members in their given contexts.

\section{Literature Review}

Three features of literature on African migrants in South Africa (SA) are noteworthy. First, the first wave of research focussed on individual migrants or households (see Crush and McDonald 2002; Lekogo 2008) rather than organisations. In fact, Crush and McDonald (2002, p. 14-15) explicitly reject a focus on migrant community organisations in favour of a study of households and individuals since as they argue "the idea of community has little analytical value" and the unit of analysis for South African migration studies is the household. In 2005, Amisi and Ballard similarly argued that,

despite extensive hardships, refugees have by and large not organised as an aggregated group with a common political interest. Aside from a Gauteng-based NGO, the Coordinating Body of Refugee Communities (CBRC), attempts to bring refugees together have failed. (2005, p. 3).

The tendency to undervalue collective organisations among migrants is also evident in later work by Landau and Freemantle (2010, p. 376) who highlight the "fragility and fragmentation of migrant associations". They assert that there "are instances in which migrant groups assert a collective (usually national) identity, (but) these are often based on instrumental and shortlived associations" (Landau 2010, p. 10).

Second, supporting the bias against studying networks and collectives is the idea that migrants are transient, take a short-term view and are too vulnerable to organise protests. Perberdy and Crush (1998) found fewer "than $4 \%$ of African migrants interviewed intended on staying in South Africa". The literature has largely argued that RAs "express an extreme dislike for living in SA" and hope conditions in their countries will one day allow them to 
return (Amisi and Ballard 2005). Mundell and Carone (2016, p. 504) explicitly argue that individual solutions such as finding a lawyer or an NGO to take up one's case are preferred by African cross-border refugees and asylum seekers, especially women, whose vulnerability makes them abjure collective action: "Their tenuous position in South African society has left most women feeling too vulnerable to participate in social protest." The upshot of this overly negative assessment has been a preference for studying the single person, or the household as the unit of analysis. New research, however, shows that fewer than $40 \%$ of Rwandans and $15 \%$ of Somalis wish to return home and only $10 \%$ of Rwandans and $30 \%$ of Somalis have been home at least once since moving to Cape Town (Nzabamwita 2015).

Third, in cases where African migrant networks have been researched, the focus has been with their entrepreneurial skills and networks (Kalitanyi and Visser 2010; Tengeh et al. 2012). Another group of scholars such as Hlatshwayo (2011, p. 169) argue that unions played an "important role in providing humanitarian aid to victims of xenophobia in 2008, but COSATU has still not developed a strategy for organizing migrants". While Morreira (2010) and Crush and Chikanda (2015) recognise the role of migrant social networks, this is done within an NGO context, and en passant. The global bias in scholarship towards methodological individualism and the legal positivism of human rights liberal scholars have as Castles (2002, p. 1145) argued, understated "the character of migration as a collective process based on the needs and strategies of families and communities".

\section{Approach and Methodology}

Given the dominant "methodological individualism" and gaps in recent migration scholarship in South Africa, a fresh theoretical perspective and empirical focus is needed. We sorely lack knowledge about organised RAs formations, the activities and services they offer, their geographical reach and location, who they assist and what sorts of resources they can mobilise. Our approach is motivated by three reasons: First, migration by single persons with no connections to networks is regarded as exceptional since "individual migrants seldom enter a country or participate in its politics on their own. Migration is a networkcreating process that stimulates individuals to construct new social relationships" (Portes 1995, p. 22). Second, foreign African migrants from similar backgrounds tend to cluster geographically and in economic sectors in SA (McDonald 2008; Tengeh et al. 2012). This also facilitates concertation and organisation, although some arrive as highly skilled professionals, some as students and others as semi-skilled workers (the largest group) while others are RAs who often settle in townships (McDonald 2008). According to Sichone (2008, p. 317) "African migrants in Cape Town, do not exist as individuals but always as holders of various group identities ... it also provides an alternative citizen- ship to that of the nation-state".

Third, the lives of cross-border African migrants in some cases centre on the ongoing relations between migrants and their places of origin as well as integrating into their host communities creating "dual loyalties. The back-and-forth traffic builds multifaceted social fields spanning national boundaries" (Portes et al. 2008, p. 1057). Portes shows that "immigrant groups finding themselves discriminated against, bond together through their organisations and adopt a defensive stance toward the host country while at the same time 
appealing to symbols of cultural pride brought from home" (2008, p. 1063). Portes et al. (2008, p. 1064) therefore argue that "the organizational life of immigrant communities is not as segmented as it appears at first glance and that transnational organizations may actually serve as vehicles for successful integration".

Strang and Ager (2010, p. 597) suggest that RAs organisations provide resources in three key areas: information and material resources; emotional resources, which enhance confidence; and finally, capacity building resources. They argue that the "value derived from networks also shifts over time, with the emphasis moving from the material to the emotional". These organisations can be defined by what they do, the groups they serve, their aims, how they raise funds, the strategies they use, their fragility and their leaderships. Some are more exclusive than others.

Drawing on these observations, the qualitative research for this paper is based on in- depth, semi-structured, face-to-face interviews lasting up to 3 hours with leaders of 11 organisations of three migrant groups selected for the study. We also used a snowballing technique to reach the 11 organisations. The research draws on 3 years of work with migrants with one author working as an interpreter for RAs at the Department of Home Affairs (DHA) in Cape Town.

Our interviews were about the principal objectives of the organisation, the problems their members experience in South Africa, organisational activities in South Africa and beyond and the organisation's ties with South Africans. A few limitations of this study need noting. All leaders interviewed were males. Leaders are usually well educated males often founder members of organisations with many having permanent South African residence (Author Interviews; ISD 2018).

After doing the fieldwork, we found that there is a women organisation in Cape Town that is called South African Somali Women's Network (SASOWNET). We did not include NGOs that work with migrant organisations, or interview the members of organisations or observe organisational meetings in a systematic way.

\section{Overview of Groups Studied}

The South African immigration context is very complex since the country is itself a deeply divided society with its own internal migration problems (Bond and Ruiters 2017). In South Africa, cross-border RAs often move into already marginalised black communities within the "racialised economic geographies" of the neo-apartheid city (Morreira 2010; Bond and Ruiters 2017). Middle-class professional African economic immigrants typically become dispersed in former white suburbs. But poorer African cross-border migrants have to self-settle often in tightly knit clusters and without white skin privileges accorded to European migrants. It is important to differentiate between different types of refugees-political, economic and climate change refugees and different class situations of such persons. Even if xenophobia is commonly experienced, different groups have different exposure to threats and violence. 
Non-nationals made up 3.7\% of the Western Cape's population-187,000 people (RSA, 2011). Almost half $(94,000)$ of these international migrants were recent mi- grants, having relocated to SA between 1 and 5 years before the census in 2011 (RSA 2011).

Somalis comprised almost a quarter of all refugees in South Africa. Between 24,000 and 27,000 Somalis resided in South Africa in 2011; two thirds arrived between 2005 and 2011 (Statistics SA 2012). The majority of Somalis reside in just two provinces: the Western Cape and Gauteng suggesting a purposeful geographical pattern. And as pointed out by Jinnah (2016, p. 13) "The Hawiye are from southern Somalia, and most Hawiye in SA live in Cape Town". Most Somalis had formal refugee status with 8\% holding South African citizenship thorough naturalisation (Jinnah 2016, p. 3). According to UNHCR in 2018 "Some Somalis in South Africa have expressed interest in eventually returning to Somalia; however, most of them prefer to wait until the situation in the country stabilizes" (https://reliefweb.int/report/southafrica/unhcr-special-envoy- somalia-commends-south-africa-generously-hosting-thousands).

Self-employed with many owning or running home-shops (called spazas) in Cape Town's black townships, Somalis are the main victims of crime and xenophobia (Charman and Piper 2012). More than 5000 Somalis also work in the retail sector in a concentrated enclave in the former white area of Belville (IoL 11 May 2011, www.iol.co. za/news/south-africa/...cape/bellvillea-safe-haven-for-somalis-1067257). It is no surprise therefore when people call this part of Belville Blittle Mogadishu. People know about Belville, even in Somalia. When some new Somali refugees arrive in the country, they prefer coming straight to Belville (Rashid, cited in Africa Witness, 2011/08/04).

Owen observes that unlike Somalis, most Congolese live in suburbs not former black townships (2015). Armed conflicts in the Congo led Congolese to come to SA (Owen 2015). Congolese RAs have since the early 2000's settled in Cape Town. Congolese working class migrants have reportedly found work in the security industry and car guarding in Cape Town's CBD and they also hold positions as French teachers, waitrons, managers and bouncers (Cape Argus, July 26, 2009). Some own small businesses and reside in dispersed microcommunities in Maitland, Muizenberg, Salt River and townships like Delft (Author Interviews 2014). Congolese although divided politically over politics in the DRC have mobilised public collective protest after numerous xenophobic murders of Congolese refugees in Cape Town. Several marches have been organised against "the notoriously inept Department of Home Affairs local offices" (Amisi and Ballard 2005). Rwandan migrants fled their country after the civil war that started in 1990 arriving in South Africa the late 1990s. This war forced 1.7 million Rwandan citizens to look for asylum in neighbouring countries (Appleyard 1998, p. 193). Many Rwandan refugees have been in South Africa for over 15 years and have established local social and economic roots (Gunn 2013). In fact, as Gunn (2013) points out one third of the Rwandan Refugees were born in SA. Rwandan informants indicated that one can experienced "bad reception from one's countrymen" who suspect that refugees are deliberately "sent by the Rwandan government to spy on them" (Author Interviews 2014). There is evidence that RAs are divided, carrying conflicts from their home countries to the host country. 
Rwandans have for the most part found work in customer care at different shopping malls, and in the metered taxi industry (Author Interviews 2014). Furthermore, they tend to be poor, vulnerable and in a more precarious legal situation since the threatened revoking of their refugee status in 2011 (Kavuro 2015). On December 30, 2011, the UNHCR issued a formally declared Rwanda a safe country for Rwandan refugees to return, thereby signalling to their host countries to apply a cessation clause that would, among other things, revoke their refugee status.

\section{Somali Organisations and Activities in Cape Town}

In this section, we look at the variety of organisations, major challenges and activities among our case study RAs organisations. The oldest organisations are Somali (formed in 1998) while all the others were formed after 2004. While all Somali organisations have physical offices in Bellville, most organisations created by Rwandan and Congo- lese do not. Like Somalis, all Congolese organisations are legally registered as non- profit organisations. The Congo Square News (CSN) is the youngest organisation created in 2011.

Among Cape Town Somalis, this study found that there were at least four different, formal membership-based organisations with leaders that functioned regularly after 2004. These were the Somali Association of South Africa, the Somali Community Board of Cape Town, the Albayaan Islamic Council Trust and the Ogaden Community of SA. These organisations have been deeply affected by xenophobic attacks in urban Cape Town. All the four Somali organisations were legally registered as non-profit organisations (author interviews). These organisations have offices in Belville and contrary to many scholars cited earlier, these organisations have proved to be durable.

Started in 1998, the Somali Association of SA (SASA) defines itself as a domestic, social service and educational organisation. It has branches in different provinces. A member of the Western Cape Migrant Forum, and the Association for Refugee Community Organisations in South Africa, this organisation has two main objectives: "to integrate the community into the South African society and to liaise with the South African government and civil society organisations to help the Somali community" (Interview Khalif). It has close ties with a local NGO (Scalabrini) and in 2014 assisted over 500 individuals and has held meetings with police and healthcare providers on issues affecting refugees in the area. The Western Cape Chairperson of SASA implored during a training session he was conducting for black South Africans: "Let's work together. I am a black person. I am poor. I ran away from war ... We should not blame each other" (cited in "Somali businessmen share their acumen with locals" in Ground up 25th February 2015). The second large organisation, the Somali Community Board (SCB), founded in June 2007 is a national political umbrella body that is open to all Somalis in South Africa. With offices in Johannesburg (where is has mass membership) and Bellville (Cape Town) and in war torn Mogadishu, it supports all Somalis, but also focuses on political activities in Somalia where it is affiliated to the ruling party. The Somali Community Board's objectives are 
to get Somali people together, to help community members who are in need, to help community members to access their rights; and to motivate members to preserve their culture and religion (Interview Sheikh).

Sheikh, the chairperson of SCB in the Western Cape and Director of Township Business Development, has lived in SA since 2003. He has retail businesses and supplies migrantowned shops in the townships. With the attacks on foreign-owned businesses, he formed the local SCB "with the aim of integrating Somali businesses more effectively into the townships and informal settlements where they operate" (Interview Sheikh).

The third organisation, the Albayaan Islamic Council Trust (AICT), is a domestic, educational and religious organisation formed in 2006 by Somali refugees in SA. The head office is in Johannesburg and it has more than 700 members in Cape Town with the majority being Muslims. "The group started an Islamic School in Belville because Somali children are attending far off Muslim schools. Because of that, kids come home exhausted. Having a Muslim school in Belville will help their kids to have time do their homework, play and rest" (Interview Rashid).

The AICT maintains ties with South African local authorities. "We get invited and participate like other local stakeholders in meetings organized by the Belville local authority". (Interview, Rachid). It participated in the Voortrekker Road urban regeneration project in Belville. As Rachid informed us, "We also clean Belville CBD, last year we did it twice. We have also a good relationship with Darul Islam Foundation Trust, Muslim Judicial Council (MJC) and African Muslims Agency (Interview Rachid).

In contrast to the literature that argues migrants take a short-term view of their prospects in SA, we found that these organisations have made considerable effort to invest in long-term ties with local institutions, the central government, and the parliament and to the local government. As the SCB leader Sheik remarked:

We encourage our members to attend churches of South Africans and to be part of the local community. Furthermore, we are creating street committees that will be composed by both Somalis and South Africans in order to encourage locals to protect Somalis (Interview, Sheikh).

Furthermore, the SCB leader encourages eligible members to reach out and join local ANC branches:

In SA, we have a partnership with African National Congress (ANC). Further- more, we encourage members who have South African citizenship already to join ANC. The South African government trains our members in leadership (Interview Sheikh).

However, their relationship with government could be a double-edged sword. Strang and Ager (2010, p. 598) remark that the mediating role of immigrant organisation can be complicated 
since they are widely seen, by policy makers at least, as the ideal infrastructure through which to deliver government support to dispersed refugee communities. However, this role ... led to an uncomfortable ambiguity between representing the best interests of the refugee community and representing government policy on the control of immigration.

As already noted, in order to reduce the attacks against Somalis in townships, the SCB initiated a "self-protection program" based on "street committees" in different townships. In fact, most victims of xenophobia in Cape Town are Somalis. And as an SCB leader noted, "On average, every year we lose not less than 100 Somali nationals across the country and half of that population are actually only in the Western Cape, specifically in the informal settlements areas and Khayelitsha” (ENCA 2 Feb 2017 wn.co.za/2017/02/07/14somali-nationals-killed-in-sa-since-beginning-of-2017). regarding a recent attack in Gauteng, Sheikh criticised the decision by some Somalis to get weapons, but said it was because they felt vulnerable. "The frustration of law enforcement has led to some of our members arming themselves. We condemn it but they have no option but to protect their interests" (somali-spaza-shop-owners-take-up-arms in Mail and Guardian, 1 September 2017). As Jinnah noted, Somalis are now able to fight back, organise militant counter-marches and defend themselves (ibid).

The SCB links its members with their country's fragile government through its office in Mogadishu although as already noted, few Somalis have opted to return home. The office facilitates accessing funds if refugees want to be involved in a development project back home or for matters linked to their migration status:

We have an office in Somalia to help people who go back in the country to integrate. Our office deals also with the Somali government in the matters linked to the Somali diaspora (Interview: Sheik).

As indicated by the leaders, the second biggest problem for migrants after "having proper papers" is xenophobic violence and protection. The AICT opened the mosque for people to sleep-in. Furthermore, the Imams (religious Muslim leaders) gave them a word of encouragement. This organisation with other migrant organisations took letters twice to the parliament to request protection for migrants.

Like SCB, the AICT has been involved in integrating Somalis into South African life. They do it through skills transfer initiatives in which they teach South Africans how to run a small business. The SCB leaders added;

As refugees we are helping South Africans by employing them in our businesses, teaching them how to start business. We show them where to buy goods and how to look for clients. Our organisation works with other South African Organisations. For example, some of them give scholarships to Somalis students (Interview, Rachid). 
The Ogaden Community of South Africa (OCSA) is a transnational organisation that focuses on the liberation struggle of the Ogaden region. During the xenophobia of 2008, OCSA provided vehicles to save people and their goods, and they give blankets and food:

In our country we support freedom fighting armed group that is fighting for the liberation of Ogaden region. We support also civilians who are affected by the war". (Interview Rahman).

The OCSA has claims to have a good relationship with "foreigner affairs department, the municipal government of Cape Town, United Nations and the media" (Interview Rahman). The AICT does philanthropic activities in Somalia. For example, in 2010 when Somalia was affected by the drought, it sent donations to people of Somalia. The donation was taken by Sheikh Irfan (a South African Sheikh) accompanied by many South Africans and Somali community (Interview Rachid).

The study of Somali organisations suggests five observations; firstly, they are characterised by stability, tenacity and complementary activities and overlapping memberships: one can be a member of several organisations without it affecting one's loyalty to any or producing tensions. Secondly, they link up Somalians in their own businesses and have the strongest protection networks of foreign national communities in South Africa (Jinnah 2016). Thirdly, the Somalian organisations tend to have more extensive home linkages and fourthly, Somalian refugees have access to their own, albeit besieged government for support and resources. Finally, as a recent report for the UNHCR noted, Somali respondents in Cape Town believed that their community organisations are generally effective (ISD 2018).

\section{Congolese Migrant Organisations in Cape Town}

Three Cape Town based refugee and asylum seekers organisations with members from the Democratic Republic of Congo (DRC) participated in this study; one is a media organisation, another is a social agency, the other is a home-town committee. All three organisations are legally registered. The Congolese have a cluster of organisations numbering at least 17 (Author interviews 2014). The Congolese Association of Cape Town was also noted for representing refugees and asylum seekers from Congo Kinshasa (ISD 2018). According to informants "One of the challenges in organising meetings is that many refugees work on shift for security companies. It is therefore difficult to find a time when everyone is available" (Amisi and Ballard 2005, p. 9).

The Democratic Republic of Congolese Association in South Africa (DRCASA) is a domestic registered organisation created in Cape Town in 2005. DRCASA assists its members to get proper identification papers. Its membership exceeds 1000 individuals. It organises events in which different Congolese ethnic groups come together to celebrate their diversity through cultural events (Interview, Somwe). The DRCASA also seeks to integrate members by learning local South African languages:

We encourage people with hair salons to take South Africans to work with them for skill transfers. Congolese teach them to make hair and South Africans teach them the language. 
This can help them to integrate in the local community and leave the suburbs where accommodation is very expensive (Interview, Somwe).

The Amis BK (Friends of Bukavu) is a home-town committee and transnational organisation which collects information about conditions at home and in SA, promotes life skills for members, and provides social assistance. It has more than 200 members who meet every last Sunday of the month in Mowbray and an office in Observatory. As its president and leader of Amis BK explains:

Whenever there is touching news in our country we meet and discuss and give our view on what could be a solution. We try to distance ourselves from politics since as refugees we are not allowed to be involved in politics (Interview, Namufakage).

Their activities include teaching people about HIV/AIDS, organising sport events: like the "Umoja Cup" and exhibitions of Congolese culture, solidarity activities for people affected by the war. It organises tutoring for South Africans in township schools in math and physics.

As the leader noted,

Last year when the M23 rebel group was controlling the entire East of Congo, we met with the South African parliament and raised some points like why is it keeping quiet on what is happening in Congo. They promised that they were going to send people there to analyse the situation. And we believe that our interaction with the South African parliament influenced the central government to be involved in the Congo case (Interview, Namufakage).

The third organisation, Congo Square News (CSN) was created around a newspaper in 2011. Its objectives are to inform and educate Congolese people, to keep a record of the Congolese life in SA, to promote unity among Congolese, to make the newspaper international and to provide a platform for free expression. The CSN leader explained that they realised that DRC community organisations work in isolation and people do not know enough about them:

Last time we brought together all Congolese organisations under the theme "unity among Congolese", because we saw that all Congolese organisations are working individually and we want them to come together. In that assembly each organisation was given a time to explain what it is doing. We publish stories about people who were affected by the xenophobic attacks and whenever we get information we publish them. We direct them also where they can get help, for example trauma centre so that they may be rehabilitated (Interview, Tshinkyoka).

Congolese organisations studied are interested in influencing the South African government to assist with peace keeping and fair elections in their country.

Our organisation works with the parliament on African issues. At the parliament they have also a portfolio committee that is dealing with migrant's integration. On Africa day, we come at the 
parliament as different nationalities and celebrate our diversities and make our voice heard (Interview, Somwe).

In order to help the Congolese community to integrate in the South African community, DRCASA works with the DHA: "now many Congolese are getting refugee status. The refugee status is very important: we have a case of our members who managed to get scholarships at UCT, UWC".

Amis BK has different initiatives that aimed to bring together Congolese and South Africans. The first initiative is "volunteerism". In this program, Congolese promote the social cohesion through tutoring South African students in science for free. According to the Amis BK's leader, this program ran for 2 years and stopped due to the lack of a bank account for funders' use for that project. "In 2011 and 2012 we had a volunteering project in Langa township to teach South African students maths and physics in public schools, which is part of integration" (Interview, Namufakage).

The Amis BK organises soccer matches so RAs can play soccer with local clubs. They run workshops concerning HIV/AIDS which is attended by both South Africans and foreigners. Another development is intermarriage: some Congolese are married to South Africans (also see Owen 2015). Furthermore, our informant noted that some members attend South African churches and some South Africans attend Congolese churches (Interview, Namufakage). The Congolese leader pointed out that:

In my church, the head pastor is from Congo but the assistant pastor is a Zulu and the women ministry leader is a South African. In the beginning we started with one church service in Observatory in 2001, and now we have two services; English and French service (Interview, Namufakage).

Despite xenophobic violence between SA blacks and foreign Africans, there are complex relationships of xenophilia and solidarity between black South Africans and non-national migrants (Sichone 2008; Owen 2015). Antagonism between South Africans and nonnationals is well known. Yet, there are numerous examples of the opposite as this article shows. These range from intermarriage to learning to speak an indigenous African language to sharing resources and even joint defence against xenophobic attacks.

According to DRACASA leader Somwe, his Congolese organisation was involved in the mediating between migrants and citizens with UNHCR and the City of Cape Town. In a campaign against xenophobia, they held healing seminars; skills transfer initiatives and other interventions:

We organized seminars where we invited different people including South Africans and tell them what Congolese are going through and we make it a way of healing memories of xenophobia (Somwe). 
Another respondent noted the interclass solidarity between Congolese in town- ships and the welloff in suburbs:

The Amis BK sends messages to our members who were living in the township. We asked them to come to live with us in suburbs since it is safe here. We accepted to share a room or a house and whatever we had during that period (of violent attacks) (Interview, Namufakage).

But according to Namufakage the lack of coordination with similar groups makes their activities less effective.

In the DRC, last year when the M23 rebels group started in the East of Congo, we raised funds and tried to send some assistance to Congo. ... it was not easy to give money to Amis BK. We put people who wanted to help in contact with other organisations in Congo that were helping people. We gave blankets and food and they promised us that our aid was helpful (Interview, Namufakage).

Rwandan Migrant Organisations in Cape Town The Rwandan community organisations of Cape Town are smaller than Somalis or Congolese. We surveyed two religious groups, one civic/cultural organisation, and one social services organisation. Most members of the Pentecostal Community Churches in Southern Africa (PCCSA), a religious organisation are from Rwanda but other nationalities not excluded (Interview, Mukeshimana). The Pentecostal Community Churches in South- ern Africa have a permanent office. Rwanda/Burundian Seventh Day Adventists (SDA) ministry of Cape Town (RBSDA) is also religious organisation and is linked to Kuils River SDA Church of Cape Town. Its members are Seventh Day Adventists coming from Rwanda and Burundi. The group was started in 2009 by people who were worshiping at Retreat SDA church in Cape Town. They felt a need to pray in home languages in order to accommodate new-comers and elderly people who were struggling with English. The principal objective is evangelism to migrant communities in home languages. According to our informants, this organisation has 120 members who meet every Friday evening for Sabbath opening programs. The RBSDA Ministry provides financial and moral support to their members and also visits sick people (Interview, co-ordinator).

The Rwanda Heritage Foundation (RHF) is a civic and cultural organisation that provides cultural and historical education to the young and old, and promotes unity among Rwandans. The RHF holds its meetings in Retreat, Cape Town, and has more than 200 members. Its objectives are to develop knowledge of Rwandan history, to promote the Rwandan culture and social cohesion among Rwandese (Interview, Kalitanyi). In cases of family conflict, migrant organisations also intervene.

The RHF leader felt that for Rwandans to be integrated in the South African community, they need to be united first: 
South Africa, as diverse country, presents an ideal case to learn about social cohesion. With the understanding of the values of social cohesion, Rwandans would be in a better position to integrate in the South African society (Interview, Kalitanyi).

The Rwandan Refugees of Cape Town (RRCT) is a cultural and a social service organisation that works with both refugees and asylum seekers from Rwanda who live

in Cape Town. Formed in 2003, it helps its members financially and through advocacy and promotes the Rwandan culture among the younger generation. RRCT has more than 2000 members. Its activities in Cape Town are raising funds to help orphans, cover funeral and wedding expenses, conflict resolution initiatives, cultural events, advocacy and fighting xenophobia (Author interviews 2014).

The RRCT's Bavugamenshi explains:

If there is a dispute between some member's friends or married couples, they call us so that we can intervene. We are mostly involved in family matters... People with problems call us and we help them to solve their differences. Our members don't have funeral policies. ... it is the responsibility of our organisation to take charge of all funeral expenses. Furthermore, we help orphans left by deceased parents. In our culture, we believe that nobody does the wedding alone. When our members want to get married, we raise funds to cover the wedding costs (Interview, Bavugamenshi).

The RRCT maintains ties with SA political authorities. According to its leader, this organisation has a "good" relationship with the DHA and different human rights organisations:

Our organisation has a close tie with the Department of Home Affairs. Sometimes we invite HA to come to our meetings and we tell them our problems and they advise us on what to do. We have been interacting with high authorities in this country like ministers, deputy minister, regional and local Home Affairs authorities (Interview, Bavugamenshi).

The RRCT in 2008 was involved in anti-xenophobia campaign which were organised by the Human Rights Organisations. It is evident that Rwandan RAs organising has been multifaceted, determined and sustained.

\section{Common Issues among Organisations}

As is well documented, foreign African migrants face many problems but are affected by these in different ways (Landau 2006). There is evidence that RAs are more willing to counterorganise against xenophobic attackers and organise effective self- protection to prevent some kinds of attacks. Protection remains a key issue and this perhaps is a difference between refugee networks and normal migration/national/ diaspora networks. 
In our research for this article, organisations' leaders said the number one problem is that African cross-border migrants in general faced in 2013-2014 is obtaining "proper papers" from DHA (also see Landau 2006 for an account of state shortcomings in issuing 'recognizable identity documents' for refugees). Landau (2006) has argued that having correct documents issued timeously by from DHA is an indispensable first step in securing protection and dignity for refugees. Among the 11 leaders of the different organisations interviewed, eight claimed that their members are struggling with getting valid Home Affairs papers.

Our fight is on the issue of papers. Because the majority of our members are using asylum seekers permits. Another issue is that now the Home Affairs office is going to close in Cape Town so it is going to be difficult for people who don't have refugee status to survive in this city (Interview, Somwe).

This was echoed by a Congolese leader:

... For someone to survive in SA he has to have an identity. If someone doesn't have proper papers, it constitutes a barrier to education, livelihood, and employment. And this has an implication for integration. What is causing people not to be integrated is documents (Interview, Somwe).

The leader of Rwanda Refugees of Cape Town explained his perception of the situation:

....Some people have asylum seekers papers but don't have the refugee status ... there are others who have refugees status for more than 10 years but they don't have Permanent Residence whereas normally a person should have Permanent Residence in 10 years. Normally, kids born here should be granted citizenship as it is accepted by the international laws. But here it not being done, this is frustrating (Interview, Bavugamenshi).

The Amis BK leader echoed the same frustration:

Applications for asylum for some of our members are being rejected whereas the situation in the east of Congo is not stable yet. Even those who have been accepted, they are given temporary documents that need to be extended periodically (Interview, Namufakage).

The Amis BK leader revealed that in SA, there is a "system designed to exclude migrants and the tool that is being used is identification documents". Migrant leaders believe that migrants should become naturalised citizens as soon as possible. They also agreed that giving citizenship to migrants will not affect their relationship with their home countries and SA. Echoing Portes et al. (2008), they agreed that, Bit is possible to be loyal to Somalia/Rwanda/Congo and at the same time be a good South African citizen". However, some leaders raised their concerns about acquiring SA citizenship. Leaders from DRC asserted that they are not willing to lose their Congolese citizenship: 
... until now the DRC constitution does not accept the double nationality. So my worry is that once you became SA citizen you lose your DRC nationality. And many Congolese don't want to lose their citizenships (Interview, Tshinkyoka).

He pointed out also that even if with a South African identity document or ID, "you will still be discriminated against and attacked since it will always highlight your country of origin". In short, the DHA is a key factor and ongoing obstacle for migrant organisation (Crush 1997; Landau 2006). Shirley Gunn (2013:16) argues, "Consultation with all relevant stakeholders is key to developing policy on migration and should include membership-based organizations, formed by refugees themselves, like RRCT".

Foreign African migrants of all classes like black South Africans are also deeply affected by racism and institutional discrimination where landlords, for example, routinely refuse to rent to all blacks (Lemanski 2004; McDonald 2008). Lack of access to banks is a problem that RAs face (McDonald 2008). While discriminated against by South African financial institutions, those RAs in need turn to their organisation for funding. The Somali Community board and DRCASA have specific programs reserved for that: according to Rashid, his organisation "collects money from members in order to help some members to start their own small businesses"-much like a stokvel or community bank.

But RAs face many problems aside from xenophobia and discrimination. The Somali community faces a problem of a drug called "Milajad". This drug is a herb that grows in Eastern Africa especially in Ethiopia. According to the AICT's leader, it is affecting Somali youth and South Africans are joining them.

Language barriers were a problem when accessing health services. The AICT's leader asserts that Somali women are being sterilised without their consent-serious human rights violation that is increasingly being researched and exposed:

... when our women go to maternity they are abused and given family planning without their consent. Some of them find out that they can't have kids anymore while they didn't know when they have been sterilized. I think it is because many of them don't know English and are forced to sign what they don't understand (Interview, Rachid).

\section{Conclusions}

This paper started with a concern that much of the most cited literature on cross-border refugees and asylum seekers in South Africa is based on methodological individualism and has consequently underestimated the role of migrant self-organisation which were dismissed as fragmented, ineffective and short lived. This paper has suggested that on methodological and empirical grounds, these negative assumptions and findings are misplaced. Migration of refugees and asylum seekers, we have argued in this paper, is a network-creating collective process that shapes how individual migrants and their families construct social relationships and get organised. RAs organisations form a major element of networks 
(formal and informal) that promote both transnational and local collective action. Migrant organisations provide proactive collective protection and undertake important initiatives to build relationships with South Africans. The findings of this article show that refugee-led organisations provide vital physical, social, moral and sometimes financial support. The fact that these organisations have persisted for over decade, have formal office bearers, are registered as NPO's, can mobilise resources and have memberships speaks to the determination of migrants collectively to build new lives for themselves in Cape Town. Since 2008, RAs and those with permanent residence have also steadily become more organised to defend themselves against attacks.

It is evident that migrant organisations have varying approaches, resources and strengths to their different and sometimes common challenges. The three groups of organisations (Somalian, Congolese and Rwandan) function in geographically specific ways; each has different strategies and inward and outward orientations while facing different sets of problems. Those living and working in townships are the most vulnerable but also have become more organised such as seen in the Somalian street committees. Many have consciously tried to assimilate with South Africans (learning local languages, marriage and joint activities) while others (especially Congolese and more recently Somalians) have not shied away from open protest. Churches and mosques are also central social nodal points. Transnational RAs organisations are often divided by gender, ethnic, class and religion and power differences. While recognising their weaknesses and their crucial collective roles we need to avoid reifying these organisations as "sole spokespersons for "communities". Having a diversity of voices is not necessarily a weakness and need not be characterised as fragmentary. The research thus confirms the importance of organised migrant communities while avoiding easy assumptions about coherent nationality-based groups. Several of the key leaders we interviewed spoke of pan-africanism and black solidarity.

Most leaders of the organisations we interviewed projected a positive future in SA with no contradiction between successful integration into the host society and keeping their own culture and links with home. The links between formal and informal networks need to be further explored. Because this study was based on leaders' viewpoints, there is a need for more knowledge to be generated about the memberships, their class and gender composition and so on. The positive roles that can be played by migrant organisations in building respect for difference in SA and building agency and voice among migrants need to be further researched given the widespread methodological bias towards studying individuals and households. 


\section{References}

Amisi, B., \& Ballard, R. (2005). In the absence of citizenship: Congolese refugee struggle and organisation in South Africa. Forced Migration Studies Programme, University of the Witwatersrand.

Appleyard, R.T. ed., (1998). Emigration dynamics of developing countries: Sub-Saharan Africa (Vol. 1). Ashgate pub ltd.

Bond, P., \& Ruiters, G. (2017). Uneven development and scale politics in southern Africa: what we learn from Neil Smith. Antipode, 49, 171-189.

Castles, S. (2002). Migration and community formation under conditions of globalization. International Migration Review, 36(4), 1143-1168.

Charman, A., \& Piper, L. (2012). Xenophobia, criminality and violent entrepreneurship: violence against Somali shopkeepers in Delft South, Cape Town, South Africa. South African Review of Sociology, 43(3), 81-105.

Crush, J., (1997). Covert operations: Clandestine migration, temporary work and immigration policy in South Africa. Southern African Migration Project (SAMP).

Crush, J., \& McDonald, D. A. (Eds.). (2002). Transnationalism and new African immigration to South Africa. Cape Town and Kingston: SAMP and CAAS.

Crush, J., \& Chikanda, A. (Eds.). (2015). Mean streets: migration, xenophobia and informality in South Africa. Southern African Migration Programme.

Gunn S. (2013) Workshop Report, http://www.france-rwanda.info/article-rwandan-refugeesin-south-africa- advise-their-host-government-ahead-of-unhcr-s-recommendedinvocatio-115950553.html.)

Hlatshwayo, M. (2011). Is there room for international solidarity within south African Borders? COSATU's responses to the xenophobic attacks of May 2008. Politikon, 38(1), 169-189.

ISD, Institute for Social Development (2018) Rrefugee and asylum seeking representative structures and their communities in South Africa. Understanding the functions, roles, responsibilities, accountability and decision-making processes within refugee leadership structures., University of the Western Cape. Bellville.

Jinnah, Z. (2016). In the shadow of a state: self-settlement strategies and informal governance amongst Somalis in Johannesburg. Journal of International Migration and Integration, $1-15$.

Kalitanyi, V., \& Visser, K. (2010). African immigrants in South Africa: Job takers or job creators?. South African Journal of Economic and Management Sciences, 13(4), 376390.

Kavuro, C. (2015). Protection challenges facing Rwandan refugees in South Africa. Global Education Magazine. http://www.globaleducationmagazine.com/protection-challengesfacing-rwandan-refugees-south-africa/.

Landau, L. B. (2006). Protection and dignity in Johannesburg: shortcomings of South Africa's urban refugee policy. Journal of Refugee Studies, 19(3), 308-327.

Landau, L. B., \& Freemantle, I. (2010). Tactical cosmopolitanism and idioms of belonging: Insertion and self- exclusion in Johannesburg. Journal of Ethnic and Migration Studies, 36(3), 375-390. 
Lekogo, R.E., (2008). The dynamics of Francophone African migration to Cape Town after 1994 (Doctoral dissertation, Stellenbosch: Stellenbosch University).

Lemanski, C. (2004). A new apartheid? The spatial implications of fear of crime in Cape Town, South Africa. Environment and Urbanization, 16(2), 101-112.

McDonald, D. A. (2008). World city syndrome: neoliberalism and inequality in Cape Town. New York and London: Routledge.

Morreira, S. (2010). Seeking solidarity: Zimbabwean undocumented migrants in Cape Town, 2007. Journal of Southern African Studies, 36(2), 433-448.

Mundell, L., \& Carone, E. (2016). Models for migrant leadership: the Cape Town women's platform. African Human Mobility Review, 489.

Nzabamwita, J. (2015). Exploring the link between international migration and remittances: a case study of African immigrants in cape town, South Africa (doctoral dissertation, University of the Western Cape).

Owen, J. (2015). Congolese social networks: living on the margins in Muizenberg, Cape Town. New York: Lexington Books.

Peberdy, S., \& Crush, J. S. (1998). Trading places: cross-border traders and the south African informal sector. Southern African Migration Project.

Portes, A. (1995). Economic sociology of the sociology of immigration. New York: Russel Sage Foundation. Portes, A., Escobar, C., \& Arana, R. (2008). Bridging the gap: transnational and ethnic organizations in the political incorporation of migrants in the United States. Ethnic and Racial Studies, 31(6), 1056-1090.

RSA, Republic of South Africa (2011) Statistics SA, census 2011, Pretoria.

Sichone, O. (2008). Xenophobia and Xenophilia in Webner, P (ed) South Africa: African migrants in Cape Town. Anthropology and the new cosmopolitanism: Rooted, feminist and vernacular perspectives, New York: Berg.

Statistics South Africa (2012). Census 2011. Pretoria: Statistics South Africa.

Strang, A., \& Ager, A. (2010). Refugee integration: emerging trends and remaining agendas. Journal of Refugee Studies, 23(4), 589-607.

Tengeh, R. K., Ballard, H., \& Slabbert, A. (2012). Financing the start-up and operation of immigrant owned businesses: the path taken by African immigrants in the Cape Town metropolitan area of South Africa. African Journal of Business Management, 6(12), 4666.

\section{Interviews with Senior Leaders}

AbdilRahman Foud, leader of OCSA, interviewed in Belville, 20 May, 2014.

Abdul Khalif, a leader of SASA, interviewed in Belville, 2 June, 2014.

Abdi-Rashid Sheikh, leader of SCBSA, interviewed in Belville, 4 June, 2014. Abdul Rachid, leader of SAICT, interviewed in Belville, 4 June 2014.

Vivence Kalitanyi, founder and chairperson of RHF, interviewed in Cape Town, 5 June, 2014. Martin Mukeshimana, pastor of PCCSA, interviewed in Salt River, 8 June 2014.

Salim Bavugamenshi, the chairperson of RRCT, interviewed in Maitland, 8 June, 2014. Oliver Tshinkyoka Mulombo, the editor of CSN, interviewed at Salt River, 15 June 2014.

Jean-Jacques Somwe, the chairperson of the DRCASA, interviewed in Observatory, 24 June, 2014 . 
Coordinator of the Rwanda/Burundian Seventh Day Adventist (SDA)Ministry of Cape Town, interviewed

in Cape Town CBD, 25 June 2014.

Amani Namufakage, the chairperson of Amis BK, interviewed at Observatory, 20 July 2014.

Author Interviews, with a number of members of RAs organisations over the period 20132015 . 